\title{
Promoting PT. Essentra's Cigarette Filters through a Marketing Booklet
}

\author{
Monica Chiesa Adrian \\ English Department Faculty of Languages and Literature, Petra Christian University, Siwalankerto 121- \\ 131, Surabaya 60236, INDONESIA \\ E-mail: monicachiesa22@gmail.com
}

\begin{abstract}
PT. Essentra is a manufacturer located in Sidoarjo which produces cigarette filters and tear tape for cigarette packaging. The main problem that happened in the company is the ineffective way to introduce and promote company's product as the marketing team only uses product presentation slide as their tool. While giving product presentation, customers often get bored as it covers lot of explanation and take long time to finish one presentation. Therefore, the solution I offered for the company is to make a marketing booklet. This marketing booklet consists of information regarding the company and explanation of cigarette filter products along with the benefits that customers will have. This solution will help PT. Essentra in promoting its products and fulfill the customers' request related to a tool for them to review the company's products. By having this marketing booklet, it can help the company to introduce and promote its products and fulfill the customers' request of a tool for reviewing the company's products which PT. Essentra offered. By having this tool, PT. Essentra has additional promotional tool for helping the marketing team as well as the customers.
\end{abstract}

Keywords: Promotional Tool, Unique Selling Point, Marketing Booklet

\section{INTRODUCTION}

PT. Essentra, first introduced as Filtrona, is a foreign company whose headquarter is in the United Kingdom. It was established in around 1980, located on Berbek Industri I number 16 20, Sidoarjo. PT. Essentra is a manufacturer coordinated by one General Manager and employs more or less 200 staffers and 300 employees in the production team including the outsourced workers working in three different shifts. Its products are cigarette filters as the main product. Another product is tear tape for cigarette packaging. Its target market is cigarette companies in Indonesia, but it also accepts orders from abroad through PT. Essentra in the related country. Thus, about $70 \%$ of the products are exported to several countries such as Singapore, China, Malaysia, Philippine, Greece, and, Thailand, while the rest is sent to local clients in Indonesia. PT. Essentra has a lot of varieties of cigarette filters and that makes PT. Essentra different from other manufacturers of cigarette filter. PT. Essentra also sells flavored filter for cigarette which makes it unique.

Within three-month internship at PT. Essentra, I have discovered one problem that I can help in solving it. However, for several reasons I need to change my project. Therefore, another problem that I have found is the ineffective way to introduce and promote company's product. PT. Essentra also does not have enough tools for customers to look into. In introducing and promoting the company's product, the marketing team leans on product presentation only using presentation slide. However, there marketing team often find the customers become bored within the product presentation as it has a lot of product that need to be explained and takes long time to finish the product presentation. Moreover, customers often ask for a tool like a book or booklet for them to read later regarding the products that PT. Essentra offers. While 
actually having promotional tool to help promoting the company and the products is really helpful for a company. PT. Essentra also does not have any tools for customers if they want to look more about the company's products. To increase brand awareness, to increase customer traffic, and to help the company in spreading the information regarding company's offering are several benefits of promotion (Mishra, 2015).

Therefore, I decided to choose problem of the ineffective way to introduce and promote company's products by marketing team as my Business Communication Final Project. Due to this problem, I will make a Marketing Booklet focusing on company's main product, cigarette filters. Marketing booklet has more benefits compared to other printed tools. It can hold more information with more pages to be filled, can be used for multipurpose, and cost less money (Advantages of using booklet for business marketing in Rivonia, 2016). This tool will help marketing team to introducing and promoting the company as well as its products. Based on TonyYeshin (2006, p.7), promotion is "a planned and implemented marketing activity that both product or services appeal and changes customer behavior positively in return for an additional benefit for purchase or participation.” According to Tara Hornor (2012, Tips for better sales booklets), there are three important things in making marketing booklet.

1. Basic content

2. Organization

3. Branding

4. Graphics

\section{METHODOLOGY}

To execute the Business Communication Final Project, there are steps that have to be done before, during, and after doing the project. At the first time, I made a proposal in which I want to discuss about the problem that I have found at PT. Essentra. In the proposal, I explained the problem that PT. Essentra has and why it needs to be solved, the reason why I chose employee guidebook and slide presentation for new employees and interns' induction briefing as my as my Business Communication Final Project, the purpose of making the tool, and the steps in making the tool. I also received advices from the board of examiners regarding the project. However, as I was doing the process making of the tool, I found several problems regarding the tool that I am going to make. Therefore, I decided to change my project to the new one.

For the change of my project from the first proposal, I made another proposal consist of the new problem, the ineffective way of marketing team to introduce and promote the company's products. Along with that, I also explain why marketing booklet is the most suitable solution for the company as well as the benefits that the company and the customers will have while having this marketing booklet. The benefit for the company is that the marketing team can use this as their tool in showing and explaining the cigarette filters to the company's customers or potential customers when they have product presentation. While for the customers, this marketing booklet can they use as a tool to review again after the presentation or to refresh their memory later regarding the company's products. After that, I presented it in the progress report at the middle of the semester. It consists of the purpose of making the tool and the steps in making the tool. Even though I have not done many regarding the new project, I still got many useful advices regarding the BCFP report and also for the marketing booklet that I will make. Lastly, I got the approval to do the new project that I proposed with some revisions and feedbacks for the project to have a better result. After I got the approval from the examiners, then I need to get the approval from the company. Therefore, first thing, I met the Marketing Manager, Mr. Anthony, as well as his partner, Mrs. Lilies. I explained the purpose of my Business Communication Final Project. Then, I gave the proposal that I made contains the problem that I have found in the company and also the reasons why this problem needs to be solved. After that, I offered my 
solution to solve the problem using the marketing booklet that I will make for them. Then, I made a letter of agreement for the project and gave it to Mr. Anthony. Mr. Anthony asked for more time to read and discuss the contract with his partner, Mrs. Lilies, before signing it. After that, Mr. Anthony asked me to come to the company to talk about the contract and discuss about the marketing booklet itself regarding the design and the content. In that moment, Mrs. Lilies also participated in the discussion. Finally, they agreed with the solution offered, they asked me to work on it. My proposal got accepted and signed.

The tool for my Business Communication Project is a marketing booklet. There are 5 components: "About Us", "An Overview of Essentra Group". "Why PT. Essentra Indonesia?", "Our Products", and "Contact Us". Before that, there is "Table of Content" to help the readers, in here the customer, find what they are looking for easier. The "About Us" consists of information regarding PT. Essentra, especially PT. Essentra in Indonesia. Then, the "An Overview of Essentra Group" consists of brief explanation regarding the whole group of PT. Essentra. Next, in "Why PT. Essentra Indonesia?" consists the USP of the company. "Our Products" consists of enough explanation regarding the products offered by PT. Essentra. Last thing is "Contact Us". In "Contact Us" consists of the contact information for customers to call later when they want to place orders or ask regarding the products. In the back cover, I put the logo as well as the tagline of the company. This marketing booklet targets customers of the company as well as the new customers. In the making of the Business Communication Tool for PT. Essentra, there are several things to do. First, I gathered all the data I need to be put in the marketing booklet. In order to know the USP of the company, I interviewed the marketing representatives as well as several customers of PT. Essentra by asking them several question related to SWOT (Strength, Weakness, Opportunity, and Threat) which then I compared to its competitors. There are a total of 8 questions in the product questionnaire. After I finished interview, I wrote their answer on papers in a neater form. From that I found several benefits that the customers get and divided it into 2 groups: Products and Services. For the products, the customers claimed that there are a lot of options for them to choose the most suitable filters for their cigarette products. Not only that, PT. Essentra also offers and provides cigarette filter that is a common trend in the marketing in that time. Related to the service, the customers said that PT. Essentra offers better services compared to other filter manufacturers. PT. Essentra guarantees punctual product deliveries to its customers. The customers claimed that they always get their products right on the day that has been promised by PT. Essentra when they placed the orders. Other strength of PT. Essentra in its service is the free consultation with the experts. After I have finished the interview, I had a discussion with marketing manager to compare and exchange the idea between his opinion and the result that I got. After we both agreed with the decision, I wrote the concept of the project and organized the content. Then, I consulted and discussed the concept and the content with marketing manager, Mr. Anthony. After he approved, I started to collect the pictures of the products and other important thing that I will give to mu designer. Besides, I also consulted the draft with my advisor to get suggestion and make it better before doing the final step.

\section{FINDINGS AND DISCUSSION}

The rational of the product will be explained in an orderly manner. The justification of every decision and selection of the features will be explained further as follows:

The first section is "About Us". It consists of information related to PT. Essentra. Its purpose is to give the customers enough information regarding the company that they need to know. It is important to tell the customer enough information regarding the company they will cooperate with. Another reason having "About Us" is also to make the customers know PT. Essentra's capabilities briefly and also the benefits for buying the products of PT. Essentra. 
The second section is "An Overview of Essentra Group". This section is to let the customers know that PT. Essentra in Indonesia is a part of Essentra Group which has been known throughout the world in filter and packaging industry. This section may also bring a good impression in the customers' mind, knowing that PT. Essentra is a branch company that has been known worldwide.

The third is "Why PT. Essentra Indonesia?". In this part, there are points that explain the unique selling points of PT. Essentra or benefits that are offered by the company. The USP is divided into two groups, products and services. Here the USP of the products of PT. Essentra is related to the numerous types of special cigarette filters and the trend-based innovation. Then, the second USP of PT. Essentra is the services. They guarantee punctual product delivery and provide free consultation with experts regarding the most suitable cigarette filters that can fit the customers' product of cigarette.

The fourth section is "Our Product" which consists of explanation in each types of special cigarette offered by PT. Essentra. This part presents information along with the picture with different uniqueness on each filter.

The last section is "Contact Us". This section contains the contact information of marketing representatives of the company, their phone number and e-mail. Additionally, there is also the address and phone number of the company for customers to know.

Then, firstly, in making the tool, firstly, I chose to use minimalist style in the marketing booklet. By using minimalist design, the marketing booklet may look simple yet still look professional. Some designer also said that minimalist means "Less is More". Therefore, even the marketing booklet look simple, yet it still hold many important information that the customers need to know.

Secondly, I decided to use the same color as the word of "Essentra" in the logo of PT. Essentra for the cover of the booklet, which is gray color. For the background color of the content, I decided to use the neutral color, white. However, I still use red and purple color inside to make it prettier. I did not use purple or red as the background color in order to make the logo stands out more. I also placed the company logo in every left page in the marketing booklet to show that the company consistently ties its brand into the customers mind. White color, in advertising, is associated with cleanliness, safety, brilliance, and perfection. Gray color has a meaning of cool, neutral, and balance. It also means timeless which fit with the characteristic of the company as Essentra Group has been surviving in this industry for nearly 80 years and nearly 40 years for PT. Essentra. Then, there are other colors such as purple and red also taken from the color in the company logo. Red color symbolizes action, confidence, power, and courage. While purple is a combination of calmness from blue and fierce energy from red, often associates with royalty, devotion, and creativity. To make it look consistent, I also use the same font on each page.

Thirdly, I present some important elements such as "About Us", "An Overview of Essentra Group", "Why PT. Essentra Indonesia?", "Our Products", and "Contact Us". I considered that those things are the important things that the customers need to know. Customers tend to look for the information regarding the company as well as the benefits of being a customer there. Customers also tend to look for information about the products offer. Then, at the end, they will need to know the contact information later when they want to place an order. Also, as I have content with more than one page, such as in the "Our Product", I put "Table of Content" in beginning to help the customers find what they want easier. 
Fourthly, the marketing booklet is made in English as it is a foreign company and it makes the marketing booklet looks more professional. The language is chosen to be English as it may also be shared to customers abroad. Therefore, I made it using English language.

Lastly, the booklet is made in a portrait form as more people prefer portrait form more than landscape form. Then, I also used high quality pictures for the product pictures. I cannot just put any kind of picture. I used the high quality pictures to give the booklet a professional look.

\section{CONCLUSION}

For my Business Communication Final Project, I decided to make a marketing booklet for PT. Essentra, a cigarette filter manufacturer. Before starting doing the project, I have so many things to do as I had to find another department in the company that time. Eventually, I found the department that needs a help, then they approved the project that I proposed and were willing to pay as well.

The reason why I made a marketing booklet is because the marketing team is facing a problem. The problem is the ineffective way of marketing in introducing and promoting its products as they only rely on product presentation as their way to introduce and promote the product and do not have any other promotional tools. This may give another problem in the future as in giving product presentation marketing team has found several difficulties. The problem is the ineffective way of marketing team in introducing and promoting their products. They use product presentation as their way to introduce and promote the products. There are also customers who often ask about a tool such as a product booklet when marketing team gives a product presentation on the customers' companies.

Therefore, I offered them the idea to make a new promotional tool to help them in introducing and promoting the company as well as its products to answering the customers' request regarding the tool they ask. The promotional tool is in a form of a marketing booklet as I think it is the right solution to solve the problem that PT. Essentra has. It is the right solution it can be used not only to introduce and promote the company and its products, but also to present the unique selling points as the marketing booklet contains complete information about the company and its product that are needed to know by the customers.

There are five important elements in the marketing booklet. Those components are "About Us", "An Overview of Essentra Group", "Why PT. Essentra Indonesia?", "Our Products", and "Contact Us". I used the concept in making the marketing booklet from the online article in the internet. The article helped me a lot in doing the process making of the marketing booklet.

\section{REFERENCES}

Advantages of using booklets for business marketing in Rivonia. (2016, July 23). Retrieved

from https://www.minutemanpress.co.za/news/advantages-of- using-booklets-for-businessmarketing-in-rivonia/

Hornor, T. (2012). Tips for better sales booklets. Retrieved from https://www.google.com/amp/s/www.business2communicaty.com/marketing/t ips-

for- better-sales-booklets-0274390/amp

Mishra, A. (2015, July 23). Why is promotion important for a business?. Retrieved from https://blog.resellerclub.com/why-is-promotion-important-for-a- business/

Yeshin, T. (2006). Sales Promotion. London: Thomson Learning 